\title{
PENURUNAN PARTISIPASI ANAK USIA DINI PADA TAMAN PENDIDIKAN AL-QUR'AN
}

\author{
Jumiatmoko \\ jumiatmoko1391@gmail.com
}

\begin{abstract}
This study aims to describe the factors causing the decrease of early child participation in Taman Pendidikan Al Qur'an (TPA) Al Huda and its interaction. This research uses qualitative approach with case study method. This research was conducted at TPA Al Huda Dukuh Tanggung Desa Menjing. The sample of this study was 11 children. Data collection was conducted with in-depth interviews and participant observation. Data were analyzed with interactive model analysis. The results of this research include 1) Factors causing the decline of early childhood participation in TPA Al Huda that is a) They have received Islamic learning in kindergarten, b) They do not get special attention from parents, c) Their siblings do not participate, and ) They get Influence from more mature friends, e) They have different sects, and f) They participate in the new mosque dumping. 2) The interaction of factors causing the decline of early childhood participation in the TPA Al Huda shows that the majority of children are affected by more than one factor.
\end{abstract}

Keyword: Participation, Early Childhood, Taman Pendidikan Al Qur'an

\begin{abstract}
Abstrak
Penelitian ini bertujuan mendeskripsikan faktor-faktor yang menyebabkan penuruan partisipasi anak usia dini di Taman Pendidikan Al Qur'an (TPA) Al Huda beserta interaksinya. Penelitian ini menggunakan pendekatan kualitatif dengan metode studi kasus. Penelitian ini dilaksanakan pada TPA Al Huda Dukuh Tanggung Desa Menjing. Sampel yang digunakan dalam penelitian ini sebanyak 11 anak. Pengumpulan data dilaksanakan dengan wawancara mendalam dan observasi terlibat. Analisis data menggunakan model analisis interaktif. Hasil penelitian ini meliputi 1) Faktor-faktor yang menyebabkan penurunan partisipasi anak usia dini di TPA Al Huda meliputi a) Telah mendapat pembelajaran agama Islam di TK, b) Tidak memperoleh perhatian khusus dari orang tua, c) Kakak kandung tidak berpartisipasi di TPA, d) Pengaruh teman yang lebih dewasa, e) Berbeda aliran/mazhab, dan f) Berpindah ke TPA masjid
\end{abstract}


baru. 2) Interaksi faktor penyebab penuruan partisipasi anak usia dini di TPA Al Huda, menunjukkan bahwa mayoritas anak terdampak lebih dari satu faktor.

Kata Kunci: Partisipasi, Anak Usia Dini, Taman Pendidikan Al Qur'an

\section{A. Pendahuluan}

\section{Latar Belakang Masalah}

Anak usia dini merupakan komponen sumber daya manusia yang memiliki pengaruh besar bagi kemajuan sebuah bangsa. Telah jamak dipahami bahwa anak usia dini berada pada rentang usia 0-8 tahun. Pada rentang usia tersebut banyak penelitian berbasis neurosains yang mengungkapkan kapabilitas kecerdasan seorang individu mencapai 80\%. Golden Age populer sebagai istilah yang diyakini paling tepat untuk menamai periode kehidupan manusia tahap ini. Temuan ini mendorong setiap negara berupaya mencari, mengolah, dan mengembangkan strategi yang paling efektif bagi pendidikan yang mampu mengoptimalisasi kapabilitas yang dimiliki anak usia dini. Berbagai bentuk lembaga atau satuan pendidikan anak usia dini lahir, tumbuh dan berkembang seiring perkembangan pemikiran, konteks sosial budaya, maupun dinamisasi politis di Indonesia.

Pendidikan anak usia dini merupakan implikasi konkret dari analisis peluang dan ancaman yang menyertai karakteristik biologis dan psikis anak usia dini. Kegagalan pengelolaan, baik dari segi teoretis dan praktis, bagi anak usia dini mengakibatkan timbulnya berbagai masalah dalam ranah akademik maupun non akademik. Dalam ranah pertama, individu akan mengalami kegagalan pada jenjang pendidikan selanjutnya, berawal di jenjang sekolah dasar. Pada ranah kedua berpotensi merusak tatanan masyarakat. Kerusakan yang ditimbulkan dapat berupa drugs addiction, criminalities, mortalities, dan sexuality abuses. ${ }^{1}$ Gejala-gejala pada kerusakan tersebut telah nyata dan kemudian meningkat dalam kehidupan zaman milenial ini.

Kegagalan pendidikan bagi anak usia dini membawa dampak yang tidak bisa dibayar dengan harga murahal. Pertanggungjawabannya mencakup kehidupan duniawi dan ukhrawi. Dalam sudut pandang teologi Islam, pendidikan memiliki fungsi utama untuk membawa setiap insan manusia untuk menggapai ridha Allah SWT. Jika yang terjadi justru kerusakan yang disebabkan karena perilaku manusia maka sesungguhnya tidak ada lagi ketepatan koridor peranan pendidikan. Termasuk didalamnya sub sistem pendidikan yang paling bawah yaitu pendidikan anak usia dini. Kehidupannya harus mampu membawa anak menjadi semakin dekat dengan yang Maha Pencipta.

Khusus dalam hal ini, sebenarnya telah banyak upaya yang muncul dari tubuh masyarakat akar rumput (Grass Root) untuk membentengi generasi muda dari berbagai macam kerusakan. Masyarakat Islam khususnya telah memiliki taman-taman pendidikan Al Qur'an disetiap sudutsudut desa dan surau-surau kecil. Ada semangat sekaligus harapan untuk tetap menjaga marwah keunggulan generasi bagi masa yang akan datang. Taman-taman inilah yang berperan membina

1 Laurie M Anderson, Et al. The Effectiveness of Early Childhood Development Programs. Americans Journal of Preventive Medicine, Elsevier, Vol 24 No.3s, 2003, hal.36 
anak-anak mulai dari usia dini dengan ilmu Al Qur'an dan berbagai ilmu pengasuh akal dan jiwa lainnya. Taman ini menjadi tempat bermain, belajar, dan menempa akhlak bagi setiap anak yang menyibukkan diri di dalamnya. Muaranya, Pendidikan Agama Islam dalam bentuk TPA (Taman Pendidikan Al Qur'an) telah menjadi salah satu basis yang mengakar dan kuat bagi pendidikan anak usia dini di negeri ini.

Tepatnya pada tahun 2015, Dirjen PAUD Dikmas Kementerian Pendidikan dan Kebudayaan RI menerbitkan Petunjuk Teknis Penyelenggaraan PAUD berbasis Agama Islam. Kebijakan ini semakin menguatkan pijakan dan peran Taman Pendidikan Al Qur'an sebagai salah satu wadah pendidikan bagi anak usia dini. Komponen manajemen menjadi fokus kunci di dalamnya demi capaian PAUD berbasis agama Islam yang ideal. Hal ini memberi ruang bagi, salah satunya, TPA di Indonesia untuk menata diri menjadi lembaga yang semakin baik dan diminati.

TPA Al Huda merupakan salah satu lembaga pembinaan pendidikan agama Islam yang melibatkan anak usia dini dalam kegiatannya. Sejak berdiri tahun 2015, tercatat peserta didik kategori anak usia dini berjumlah 19 santri. Jumlah ini sebanding dengan $61 \%$ dari keseluruhan jumlah santri. Perkembangan kuatitatif yang terjadi pada tahun 2018 menunjukkan jumlah santri anak usia dini yang berpartisipasi dalam kegiatan rutin dan berkala telah berkurang sebanyak 11 santri atau sekitar $58 \%$. Angka yang cukup memprihatinkan bagi pengajar dan masyarakat maupun orang tua santri TPA Al Huda. Perkembangan zaman dengan berbagai kecanggihan teknologi dan gaya hidup merupakan faktor utama yang tanpa perlu dipertentangkan, namun faktor yang menjangkiti dari sisi internal santri memerlukan pendalaman yang lebih lanjut. Oleh karena itu, diperlukan penelaahan lebih dalam mengenai fenomena yang ada. Sehingga peneliti tertarik untuk melakukan kajian studi kasus terhadap penurunan partisipasi Anak Usia Dini pada lembaga TPA Al Huda.

\section{Perumusan Masalah}

Berdasarkan latar belakang permasalahan di atas maka dapat dirincikan perumusan masalah penelitian berupa:

a. Mengapa partisipasi santri kategori anak usia dini TPA Al Huda mengalami penurunan?

b. Bagaimana interaksi faktor penyebab penurunan partisipasi santri kategori anak usia dini di TPA Al Huda?

\section{Tujuan Penelitian}

Sesuai dengan perumusan masalah penelitian di atas maka penelitian ini bertujuan untuk:

a. Menguraikan faktor-faktor penyebab penuruan partisipasi anak usia dini di TPA Al Huda.

b. Memaparkan interaksi faktor penyebab penurunan partisipasi santri kategori anak usia dini TPA Al Huda.

\section{Manfaat Penelitian}

Penelitian ini diharapkan akan memberikan kontribusi utama bagi lembaga TPA Al Huda sehingga mampu mengetahui dan menganalisis faktor penyebab penurunan partisipasi 
santri sehingga mampu mendorong terciptanya solusi pemecahan permasalahan tersebut. Bagi masyarakat dan pemangku kepentingan menjadi sebuah laporan aktual mengenai keadaan permasalahan yang dihadapi oleh TPA dan harus segera dipecahkan bersama. Serta bagi lembaga pendidikan tinggi keagamaan Islam menjadi sebuah ruang untuk terselenggaranya penelitian dan pengabdian masyarakat demi perbaikan kehidupan TPA.

\section{B. Review Pustaka}

Review pustaka penelitian ini menyajikan telaah pustaka dan penelitian relevan terdahulu yang mendukung pemahaman mengenai konsep-konsep yang digunakan dalam penelitian ini. Konsep yang didefinisikan dalam penelitian ini meliputi partisipasi, anak usia dini, dan taman pendidikan Al Qur'an.

\section{Partisipasi}

Subjek utama dalam Taman Pendidikan Al Qur'an adalah Guru (ustadz/ustadzah) dan santri. Partisipasi santri dalam kegiatan TPA menjadi tolok ukur minat masyarakat dan keberhasilan penyelenggaraan TPA. Partisipasi dapat dipahami sebagai keterlibatan seorang atau sekelompok orang dalam suatu kegiatan. Keterlibatan yang dimaksud dapat terjadi dalam bentuk fisik, mental, dan emosi demi mencapai suatu tujuan tertentu. ${ }^{2}$ Tujuan utama masyarakat melibatkan anak-anak dalam kegiatan TPA adalah mewujudakan generasi yang cakap secara kognitif, afektif, dan psikomotorik khususnya dalam bidang pendidikan Al Qur'an.

Partisipasi dapat pula lahir ketika sebuah komunitas masyarakat menghadapi sebuah permasalahan, kemudian secara kolektif mengkaji berbagai alternatif pemecahan masalah, membuat keputusan, dan memecahkan masalahnya. ${ }^{3}$ Kadar masalah yang merundung kehidupan anak-anak pada zaman milenial ini sungguh sangat pelik diurai simpul-simpulnya. Partisipasi dalam TPA menjadi sebuah keputusan penangkalan permasalahan yang dihadapi masyarakat. Partisipasi membutuhkan keterlibatan masyarakat bagi pembangunan diri, kehidupan, dan lingkungan mereka. ${ }^{4}$

Dalam konteks penelitian ini partisipasi dapat dipahami sebagai keterlibatan santri dalam berbagai kegiatan yang diselenggarakan TPA Al Huda dalam bentuk kegiatan rutin maupun berkala. Adapun mengenai makna penurunan partisipasi dipahami sebagai berkurangnya kuantitas santri yang terlibat dalam berbagai bentuk kegiatan TPA Al Huda pada tahun 2018.

\section{Anak Usia Dini}

Sebuah pesan "Tuntulah ilmu dari ayunan hingga liang lahat " menjadi pijakan semangat bagi pemantapan konsep dan praktik bagi pendidikan anak usia dini. M Quraish Shihab kemudian

2 Siti Irene Astusi D, Desentralisasi dan Partisipasi Masyarakat dalam Pendidikan, Yogyakarta: Pustaka Pelajar, 2009, hal.31-32

3 Fasli Djalal dan Dedi Supriadi, Reformasi Pendidikan dalam Konteks Otonomi Daerah, Bandung: PT. Rafika Aditama, 2001, hal. 201-202

4 Britha Mikkelsen, Metode Penelitian Partisipatoris dan Upaya-upaya Pemberdayaan: Sebuah Buku Pegangan Bagi Para Peneliti Lapangan, Jakarta: Yayasan Obor, 1999. hal.64 
menambahkan semangat tersebut melalui istilah Paul Lengrand sebagai Long Life Education. ${ }^{5}$ Memulai pendidikan yang sebaik-baiknya pada masa muda (selanjutnya diredaksikan dalam usia dini) dan melanjutkannya serta tidak berhenti sebelum usia seorang manusia di dunia habis. Dalam penelitian klinis, anak usia dini memiliki rentang usia 0 tahun sampai 8 tahun. Pada rentang ini catatan kapabilitas kecerdasan seorang manusia mencapai taraf $50 \%$ ketika berusia 4 tahun dan $80 \%$ ketika mencapai usia 8 tahun. ${ }^{6}$ Sehingga, dimanapun dan dalam bentuk pelayanan lembaga apapun anak usia dini menjadi subjek yang amat berisiko sekaligus menarik dalam pendidikannya.

Pendidikan, khususnya yang berbasis agama Islam, bagi lembaga yang melibatkan anak usia dini di dalamnya wajib memahami dan melaksanakan prinsip-prinsip yang meliputi ${ }^{\top}$ : Mengacu pada agama islam dan hadist, bersinergi dengan lembaga/satuan pendidikan TPA/ TPQ, TKA/TKQ, TBA, TAAM, dan bentuk PAUD Agama Islam sejenis lainnya, belajar melalui bermain, berorientasi pada tahapan perkembangan anak, Berpusat pada anak, pembelajaran aktif, berorientasi pada pengembangan nilai-nilai karakter, berorientasi pada pengembangan kecakapan hidup, didukung oleh lingkungan yang kondusif, berorientasi pada pembelajaran yang demokratis, dan pemanfaatan media belajar, sumber belajar, dan narasumber. Jadi, anak usia dini dalam penelitian ini merupakan santri usia 0 tahun sampai 8 tahun yang terlibat dalam kegiatan TPA Al Huda.

\section{Taman Pendidikan Al Qur'an}

Dalam tatanan kelembagaannya PAUD dibedakan menjadi dua yaitu PAUD Formal dan non Formal. ${ }^{8}$ Taman Pendidikan Al Qur'an merupakan salah satu lembaga yang dapat dikategorikan ke dalam lembaga PAUD non formal berbasis pendidikan agama Islam. Konsep ini di dorong tumbuhnya kesadaran dan gerakan pendidikan agama Islam yang dapat diintegrasikan dengan PAUD. Pada mulanya bentuk PAUD tersebut diinisiasi oleh lembaga/organisasi Islam seperti Badan Komunikasi Pemuda Remaja Masjid Indonesia (BKPRMI), Muslimat NU, 'Aisyiyah dan lainnya.Sasaran peserta didik PAUD berbasis Pendidikan Agama Islam adalah anak dan keluarga muslim mulai usia 2 sampai dengan 6 tahun.

Penyelenggaraan pendidikan TPA menjadi salah satu struktur pembentuk pendidikan nasional. TPA mengandung nilai dan strategi tersendiri dalam upaya mengkondisikan kepribadian anak dalam bingkai pendidikan agama Islam dalam mencapai tujuan pendidikan nasional. ${ }^{9}$ Lengkapnya, Taman Pendidikan Al Qur'an adalah lembaga pendidikan dan pengajaran Islam luar sekolah atau non formal untuk anak-anak sampai dengan usia 12 tahun dengan tujuan

5 M.Quraish Shihab, Membumikan Al Qur'an, Bandung: Mizan, 1992, hal. 178.

6 Ernawulan Syaodih dan Mubiar Agusin, Bimbingan Konseling untuk Anak Usia Dini, Jakarta: Universitas Terbuka, 2008, hal. 2

7 Direktorat Pembinaan Pendidikan Anak Usia Dini, Petunjuk Teknis Penyelenggaraan PAUD Berbasis Pendidikan Agama Islam, Dirjen PAUD dan Dikmas Kemdikbud, Jakarta: 2015, hal. 19-21

8 Hariwijaya, PAUD Melejitkan Potensi Anak dengan Pendidikan Sejak Dini, Yogyakarta: Mahardika Publicity, 2009, hal. 18

9 Tasyrifn Karim, Panduan Kurikulum dan Pengajaran TKA/TPA, Jakarta: LPPTKA BKPRMI Pusat, 2004, hal. 26-28 
utamanya agar anak mampu membaca Al Qur'an dengan baik dan benar sesuai dengan ilmu tajwid ${ }^{10}$ serta memiliki kepribadian Islami.

\section{Penelitian Relevan}

Penelitian yang relevan dengan penelitian ini yaitu Kontribusi Taman Pendidikan Al Qur'an terhadap Pencapaian Kompetensi Pembelajaran Pendidikan Agama Islam di Sekolah dalam Baca Tulis Al Qur'an yang dilaksanakan ${ }^{11}$ oleh Windi. Penelitian ini menghasilkan temuan bahwa TPA menyelenggarakan pembelajaran Baca Tulis Al Qur'an yang lebih efektif di banding sekolah dasar, utamanya, karena metode yang digunakan. Oleh karenanya TPA menjadi satu pilar institusi pendidikan agama Islam yang harus tetap dipertahankan.

Penelitian relevan berikutnya adalah Peranan Taman Pendidikan Al Qur'an TPA At Thohiriyah Klampok Kecamatan Purworejo Kabupaten Banjarnegara dalam Pembinaan Akhlak.

${ }^{12}$ Mulyati. UNNES.2005. Memperoleh temuan, keberhasilan pembinaan akhlak anak melalui TPA karena didukung oleh orang tua, motivasi anak, dan masyarakat.

\section{Metodologi Penelitian}

Penelitian ini menggunakan pendekatan kualitatif yang menghasilkan data deskriptif dari orang-orang dan perilaku yang dapat diamati. ${ }^{13}$ Metode yang digunakan yakni studi kasus agar tercapai uraian fenomena secara mendalam. ${ }^{14}$ Dilaksanakan di TPA Al Huda Dukuh Tanggung Desa Menjing Kecamatan Jenawi Kabupaten Karanganyar. Berlangsung dari bulan Nopember 2017 hingga Januari 2018. Sampel pada penelitian ini berjenis purposive sampling. Sampel yang sengaja dipilih karena menjadi sumber informasi tentang fenomena yang ingin diteliti. ${ }^{15}$ Sampel penelitian ini sebanyak 11 anak usia dini yang tidak berpartisipasi di TPA Al Huda. Pengambilan data dilaksanakan dengan wawancara mendalam, ${ }^{16}$ dan observasi terlibat pada aktivitas santri ${ }^{17}$ Analisis data yang digunakan yaitu Interactive model ${ }^{18}$ yang terdiri dari Data Reduction, Display Data, dan Verifikasi.

\section{E. Hasil dan Pembahasan}

Hasil dan pembahasan dijabarkan ke dalam dua bagian sebagaimana perumusan masalah

10 Chairani Idris dan Tasyrifin Karim, Pedoman Pembinaan dan Pengembangan TKA/TPA, Jakarta: LPP TKA BKPRMI, 1995, hal.2

11 Windi, Kontribusi Taman Pendidikan Al Qur'an terhadap Pencapaian Kompetensi Pembelajaran Pendidikan Agama Islam di Sekolah dalam Baca Tulis Al Qur'an, Skripsi, UIN Syarif Hidayatullah, 2009.

12 Mulyati, Peranan Taman Pendidikan Al Qur'an TPA At Thohiriyah Klampok Kecamatan Purworejo Kabupaten Banjarnegara dalam Pembinaan Akhlak, Skripsi, UNNES, 2005.

13 Lexy J Moleong, Metodologi Penelitian Kualitatif, Bandung: PT.Remaja Rosdakarya, 2007, hal.4

14 Deddy Mulyana, Metodologi Penelitian Kualitatif, Bandung: PT.Remaja Rosdakarya, 2004, hal.201

15 Nana Syaodih Sukmadinata, Metode Penelitian Pendidikan, Bandung: PT.Remaja Rosdakarya, 2005, hal.101

16 Lexy J Moleong, Metodologi Penelitian Kualitatif, Bandung: PT.Remaja Rosdakarya, 2007, hal.186

17 Burhan Bungin, Penelitian Kualitatif, Jakarta: Kencana,2007, hal.115

18 Matthew B Miles \& Michael A Huberman, Analisis Data Kualitatif, Jakarta: Universitas Indonesia Press, 1992, hal.20 
dan tujuan penelitian ini.

\section{Faktor penyebab penuruan partisipasi anak usia dini pada TPA Al Huda}

Dengan berpegang pada kaidah-kaidah analisis data yang ditetapkan dan telah dilaksanakan terhadap temuan-temuan penelitian maka dapat dipaparkan faktor-faktor penyebab penurunan partisipasi anak usia dini pada TPA Al Huda dalam tabel berikut.

\section{Tabel 1. Tabulasi Faktor Penyebab Penurunan Partisipasi}

\begin{tabular}{|c|c|c|c|c|}
\hline \multirow{2}{*}{ No } & \multirow{2}{*}{ Faktor Penyebab } & \multirow{2}{*}{ Narasumber } & \multicolumn{2}{|c|}{ Jumlah } \\
\hline & & & Angka & $\%$ \\
\hline 1 & $\begin{array}{l}\text { Telah mendapat pembelajaran agama di TK. } \\
\text { Pembelajaran agama yang dimaksud meliputi baca tulis } \\
\text { Al Qur'an, pembiasaan do'a, pembiasaan sholat, lagu } \\
\text { anak Islam, hafalan asma'ul husna, dan hafalan surat- } \\
\text { surat pendek. }\end{array}$ & TD, DO & 2 & 10 \\
\hline 2 & $\begin{array}{l}\text { Tidak memperoleh perhatian khusus dari orang tua. } \\
\text { Perhatian tersebut meliputi mengingatkan ketika anak } \\
\text { tidak masuk TPA dan pendampingan mengulang materi } \\
\text { TPA }\end{array}$ & SY, TD, AR, ANG & 4 & 20 \\
\hline 3 & Kakak kandung tidak mengikuti kegiatan TPA. & ANG, SY, AL & 3 & 15 \\
\hline 4 & $\begin{array}{l}\text { Pengaruh teman bermain yang lebih dewasa untuk } \\
\text { memilih kegiatan bermain sepeda, gawai, dan warnet }\end{array}$ & $\begin{array}{l}\text { ANG, ALF, FI, } \\
\text { AND, RA, FA }\end{array}$ & 6 & 30 \\
\hline 5 & Berpindah ke TPA lain karena perbedaan aliran/mazhab. & ALF,FI & 2 & 10 \\
\hline 6 & $\begin{array}{l}\text { Berpindah ke TPA lain karena telah memiliki masjid baru } \\
\text { di khawasan tempat tinggal }\end{array}$ & AND, RA, FA & 3 & 15 \\
\hline & Jumlah & & 20 & 100 \\
\hline
\end{tabular}

Berdasarkan paparan data di atas, dapat diuraikan pembahasan mengenai faktor penyebab penurunan partisipasi anak usia dini pada TPA Al Huda sebagai berikut:

a. Sebanyak 2 anak atau setara $10 \%$ mengungkapkan bahwa mereka telah memperoleh pembelajaran agama Islam di TK. TK yang dimaksud adalah TK berbasis Islam, sehingga muatan materi pendidikan agama Islam sebagian besar sama bahkan lebih banyak jika dibandingkan dengan muatan materi yang diberikan di TPA AL Huda. Narasumber menyatakan bahwa mereka telah mendapatkan materi keagamaan dalam pembelajaran TK yang meliputi: baca tulis Al Qur'an (BTQ), pembiasaan do'a-do'a harian, pembiasaan sholat, lagu anak Islam, hafalan asma'ul husna, dan hafalan surat-surat pendek.

Keadaan aktual yang terjadi di TPA Al Huda terkait materi yang diberikan kepada anak usia dini meliputi baca tulis Al Qur'an, hafalan surat pendek, dan lagu anak Islam. Untuk lagu anak Islam diberikan dalam kurun waktu 1 bulan 1 kali. Keadaan yang demikian menunjukkan adanya kesenjangan antara materi yang diperoleh anak usia dini di TK dengan yang diperoleh di TPA Al Huda. Jika dipahami lebih lanjut, Kegiatan pembelajaran yang 
diselenggarakan bagi anak usia dini harus diminati, tercapai kemampuan yang diharapkan, dan bersifat menantang. ${ }^{19}$ Kegiatan pembelajaran di TPA Al Huda memiliki kadar dan karakteristik dengan tingkat variasi dan tantangan yang lebih rendah dibanding dengan di TK, sebuah implikasi logis jika anak enggan untuk berpartisipasi di TPA. Kegiatan pembelajaran pada anak usia dini harus berisi sejumlah pengalaman belajar melalui kegiatan bermain yang menarik dan menantang serta diberikan berdasarkan potensi dan tugas perkembangan yang harus dikuasai. ${ }^{20}$ Ustadz/ustadzah menjadi kunci utama dalam penyelenggaran pembelajaran yang tepat bagi anak usia dini di TPA.

b. Data yang diperoleh dari 4 narasumber atau $20 \%$ mengungkapkan alasan mereka tidak berpartisipasi di TPA Al Huda karena tidak memperoleh perhatian khusus dari orang tua yang meliputi tidak ada peringatan ketika tidak mengikuti TPA maupun pendampingan dalam mengulang materi yang diberikan di TPA. Latar belakang orang tua narasumber yang menyatakan alasan tersebut meliputi petani dan buruhal. Salah satu narasumber memiliki orang tua tidak lengkap, hanya seorang ibu. Latar belakang pendidikan orang tua meliputi SD dan SMP dengan pemahaman agama yang kurang. Latar belakang pekerjaan, pendidikan, dan pemahaman agama menjadi faktor krusial yang amat berpengaruh bagi partisipasi seorang anak pada kegiatan TPA Al Huda.

Sebagaimana dikemukakan oleh Dahlan bahwa metode dan cara-cara mendidik yang efektif di dalam upaya membentuk keimanan anak termasuk kegiatan pendidikan agama Islam melalui TPA, guna mempersiapkan anak tumbuh dan matang secara moral, psikis, dan sosial adalah mendidiknya dengan memberi nasihat ${ }^{21}$ disertai dengan keteladanan Upaya tersebut dapat tercapai secara optimal apabila terpenuhinya syarat berupa memulainya sejak dini, berkelanjutan, tegas, dan berkembang dari mekanistis menuju kata hati. ${ }^{22}$ Bukan lagi paksaan apalagi hanya dengan sekadar reward-reward materiil. Dalam aspek ini, harus disepakati bersama bahwa orang tua adalah pembina pribadi yang utama dalam kehidupan seorang anak. ${ }^{23}$ Bertanggung jawab penuh dunia akhirat.

c. Berikutnya, sebanyak $15 \%$ atau 3 narasumber menungkapkan faktor penyebab tidak berpartisipasi di TPA Al Huda karena kakak kandung tidak mengikuti TPA. Kebiasaan yang terjadi di TPA Al Huda, apabila seorang santri telah memasuki SMP (Sekolah Menengah Pertama) maka santri tersebut tidak akan melanjutkan partisipasinya di TPA .

Secara ideal ketika seorang santri telah memasuki usia SMP (13-15 tahun) maka harus melanjutkan ke jenjang Ta'limul Qur'an Lil Aulad (TQA), ${ }^{24}$ bukan mengundurkan diri. Ini permasalahan yang membutuhkan telaah korektif instropektif. Memahami kembali,secara

19 Novan Ardy Wiyani dan Barnawi, Format PAUD, Yogyakarta: Ar-ruzz Media, 2012, hal. 88 20 Yuliani Nurani Sujiono, Konsep Dasar Pendidikan Anak Usia Dini, Jakarta: PT Indeks, 2011, hal. 138

21 MD Dahlan, Pendidikan Anak Menurut Islam Kaidah-kaidah Dasar, Bandung: Remaja Rosdakarya, 1992, hal. 65

22 M Ngalim Purwanto, Psikologi Pendidikan,Jakarta: Balai Pustaka,1993, hal. 225

23 Zakiyah Daradjat, Ilmu Jiwa Agama, Jakarta: Bilan Bintang, 1976, hal. 71

24 Kementerian Agama Kanwil Jabar, Petunjuk Teknis Pendirian dan Perpanjangan Ijin Penyelenggaraan TKQ/ TPQ/TQA di Lingkungan Kanwil Kemenag Provinsi Jawa Barat, Bandung: Kemenag Jabar, 2010, hal. 6 
maknawi yang disampaikan oleh Dahlan bahwa metode yang efektif dalam mendidik anak yaitu dengan keteladanan dan adat istiadat kebiasaan yang terjadi di masyarakat. ${ }^{25}$ Keteladanan yang dihadirkan oleh kakak kandung untuk tidak lagi melanjutkan partisipasi di TPA, yang kemudian dilegitimasi melalui adat istiadat kebiasaan masyarakat yang menganggap wajar keadaan tersebut. Pola tersebut telah berhasil membangun konsep pembenaran bagi seorang anak usia dini untuk tidak berpartisipasi dalam TPA.

d. Sejumlah $30 \%$ narasumber mengungkapkan faktor penyebab penurunan partisipasi TPA adalah pengaruh teman yang lebih dewasa untuk memilih kegiatan lain seperti bermain sepeda, gawai, dan warung internet (warnet). Tidak dapat dipungkiri bahwa manusia adalah makhluk sosial, memiliki kemampuan memberikan pengaruh kepada orang lain maupun mendapat pengaruh orang lain. ${ }^{26}$ Terlebih dengan status anak yang masih berada pada taraf usia anak usia dini, mudah mengimitasi segala bentuk dan pola perilaku yang menarik baginya di dalam lingkungannya.

Pendidikan Islam yang bertujuan mengarahkan manusia kepada kehidupan yang baik dan yang mengangkat derajat kemanusiaannya. Tantangannya berupa keluwesan dalam memahami unsur-unsur fitrah manusia beserta dialektika lingkungan luar yang semakin hari semakin berat. ${ }^{27}$ Konsep pendidikan yang tidak relevan dengan perubahan zaman, berpotensi ditinggalkan oleh masyarakat, terlebih generasi milenial yang haus akan segala bentuk kecanggihan dan inovasi. Faktor ini menjadi pekerjaan rumah yang rumit sekaligus berat bagi orang tua dan pendidik pada masa ini. Segala daya dan upaya untuk membentengi anak usia dini dari pengaruh lingkungan nyata maupun maya harus ditegakkan dengan sekokoh-kokohnya.

e. Komposisi temuan berikutnya, $10 \%$ narasumber mengungkapkan faktor penyebab tidak berpartisipasi di TPA Al Huda karena perbedaan aliran atau mazhab yang dianut oleh ustadz/ ustadzhah TPA. Perbedaan ini yang mendorong orang tua santri memindahkan santri ke TPA yang diyakini memiliki kesamaan aliran/mazhab. Fenomena ini menjadi sebuah jawaban empiris. Disampaikan dalam teorema sosiologi pendidikan bahwa struktur kebiasaan yang hidup di masyarakat, salah satunya TPA haruslah merupakan perilaku yang diakui dan diterima oleh masyarakat. ${ }^{28}$ Tanpa adanya rasa pengakuan dan penerimaan oleh masyarakat, seperti halnya karena perbedaan aliran atau mazhab, sulit bagi masyarakat sendiri untuk memberikan dukungan bagi keberlangsungan TPA itu sendiri.

f. Temuan terakhir mengenai faktor penyebab penuruan partisipasi anak usia dini TPA Al Huda yaitu sebanyak $15 \%$ narasumber mengungkapkan berpindah ke TPA di khawasan tempat tinggal. Keterangan ini merujuk pada 3 santri anak usia dini yang memilih mengikuti TPA di masjid khawasan tempat tinggal mereka yang baru saja dibangun. Dengan perpindahan ini, orang tua santri berharap para santri ini dapat memperoleh pembinaan yang 25 MD Dahlan, Pendidikan Anak Menurut Islam Kaidah-kaidah Dasar, Bandung: Remaja Rosdakarya,1992, hlm 1

26 Zuhaili Muhammad, Pentingnya Pendidikan Islam Sejak Dini, Jakarta: AH Ba’adillah Press, 2002, hal. 89 27 Muzayyin Arifin,Filsafat Pendidikan Islam, Jakarta: Bumi Aksara, 2003, hal.17

28 Soerjono Soekanto,Sosiologi Pendidikan, Bandung: Jenius, 1990, hlm. 221 
lebih maksimal dari para ustadz/ustadzahnya. Yang kedua, dengan bergabungnya para santri di khawasan tempat tinggal akan memberikan kemudahan dan kenyamanan dalam bersosialisasi dengan santri lain karena berasal dari wilayah yang sama. Sesuai dengan dua prinsip penting bahwa pengelolaan kelas dalam TPA sebaiknya berdasarkan kesamaan tingkat kelas pada sekolah ${ }^{29}$ dan wilayah asal masing-masing. Selanjutnya untuk menjadi lembaga TPA yang sukses maka harus diupayakan agar setiap 1 Ustadz/ustadzah mengajar sebanyak -banyaknya 5 santri. ${ }^{30}$

\section{Interaksi Faktor Penyebab Penurunan Partisipasi pada tiap anak}

Interaksi faktor-faktor penyebab penurunan partisipasi anak usia dini untuk masing-masing anak di TPA Al Huda dapat disimak pada sajian tabel berikut ini.

Tabel 2. Tabulasi Interaksi Fakor Penurunan Partisipasi pada masing-masing anak.

\begin{tabular}{|c|c|c|c|c|c|c|c|c|c|c|c|c|}
\hline \multirow{2}{*}{ No } & \multirow{2}{*}{ Faktor Penyebab } & \multicolumn{11}{|c|}{ Narasumber } \\
\hline & & TD & DO & SY & AR & ANG & $\mathrm{AL}$ & $\mathrm{FI}$ & AND & $\mathrm{RA}$ & FA & ALF \\
\hline 1 & $\begin{array}{l}\text { Telah mendapat } \\
\text { pembelajaran agama } \\
\text { di TK. Pembelajaran } \\
\text { agama yang dimaksud } \\
\text { meliputi baca tulis Al } \\
\text { Qur'an, pembiasaan } \\
\text { do'a, pembiasaan } \\
\text { sholat, lagu anak Islam, } \\
\text { hafalan asma'ul husna, } \\
\text { dan hafalan surat-surat } \\
\text { pendek. }\end{array}$ & V & V & & & & & & & & & \\
\hline 2 & $\begin{array}{l}\text { Tidak memperoleh } \\
\text { perhatian khusus dari } \\
\text { orang tua. Perhatian } \\
\text { tersebut meliputi } \\
\text { mengingatkan ketika } \\
\text { anak tidak masuk TPA } \\
\text { dan pendampingan } \\
\text { mengulang materi TPA }\end{array}$ & V & & V & V & V & & & & & & \\
\hline 3 & $\begin{array}{l}\text { Kakak kandung tidak } \\
\text { mengikuti kegiatan TPA. }\end{array}$ & & & V & & V & V & & & & & \\
\hline 4 & $\begin{array}{l}\text { Pengaruh teman } \\
\text { bermain yang lebih } \\
\text { dewasa untuk memilih } \\
\text { kegiatan bermain } \\
\text { sepeda, gawai, dan } \\
\text { warnet }\end{array}$ & & & & & V & & V & V & V & V & V \\
\hline 5 & $\begin{array}{l}\text { Berpindah ke TPA lain } \\
\text { karena perbedaan } \\
\text { aliran/mazhab. }\end{array}$ & & & & & & & V & & & & V \\
\hline
\end{tabular}

29 As'ad \& Budiyanto, Pedoman Pengelolaan, Pembinaan, dan Pengembangan TPA-TPA Nasional, Yogyakarta: LPTQ Nasional,1995, hal. 31

30 As'ad Humam \& Budiyanto,Pedoman Pengelolaan, Pembinaan, dan Pengembangan TPA-TPA Nasional,Yogyakarta: LPTQ Nasional, 1995, hal. 19 


\begin{tabular}{|c|l|c|c|c|c|c|c|c|c|c|c|c|}
\hline \multirow{2}{*}{ No } & \multirow{2}{*}{ Faktor Penyebab } & \multicolumn{10}{|c|}{ Narasumber } \\
\cline { 2 - 12 } & TD & DO & SY & AR & ANG & AL & FI & AND & RA & FA & ALF \\
\hline 6 & $\begin{array}{l}\text { Berpindah ke TPA lain } \\
\text { karena telah memiliki } \\
\text { masjid baru di khawasan } \\
\text { tempat tinggal }\end{array}$ & & & & & & & & & & & \\
\hline $\begin{array}{l}\text { Interaksi antar faktor tiap } \\
\text { narasumber (\%) }\end{array}$ & 33 & 17 & 33 & 17 & 50 & 17 & 33 & 33 & 33 & 33 & 33 \\
\hline
\end{tabular}

Berdasarkan tabel di atas, interaksi faktor terendah sebesar $17 \%$ yang terjadi pada 3 narasumber, interaksi faktor tertinggi sebesar $50 \%$ yang terjadi pada 1 narasumber. Sisanya sebesar $33 \%$ terjadi pada 7 narasumber. Data tersebut memberikan pemahaman bahwa pada mayoritas anak, faktor-faktor yang menyebabkan penuruan partisipasi di TPA Al Huda lebih dari satu faktor. Faktor-faktor tersebut saling berinteraksi dan berimplikasi bagi penurunan partisipasi anak usia dini di TPA Al Huda.

\section{F. Simpulan dan Rekomendasi}

Simpulan penelitian ini meliputi: 1) Faktor-faktor penyebab penuruan partisipasi anak usia dini di TPA Al Huda yaitu a) Telah mendapat pembelajaran agama Islam di TK, b) Tidak memperoleh perhatian khusus dari orang tua, c) Kakak kandung tidak berpartisipasi di TPA, d) Pengaruh teman yang lebih dewasa, e) Berbeda aliran/mazhab, dan f) Berpindah ke TPA masjid baru. 2) Interaksi faktor penyebab penuruan partisipasi anak usia dini di TPA Al Huda,menunjukkan bahwa mayoritas anak terdampak lebih dari satu faktor.

Rekomendasi penelitian ini khususnya bagi lembaga TPA Al Huda, sebaiknya dilaksanakan perbaikan konsep dan kualitas pembelajaran, sumber daya manusia (usatadz/ustadzah), dan memperkuat dukungan orang tua serta masyarakat. Penelitian lanjutan yang dapat dilaksanakan guna mengkaji lebih dalam mengenai partisipasi anak usia dini di TPA yakni terkait faktor kebijakan Full Day School (FDS), peningkatkan akses gawai berinternet, dan pergeseran gaya hidup masyarakat Islam.

\section{Bibliografi}

Anderson, Laurie M, Et al, The Effectiveness of Early Childhood Development Programs. Americans Journal of Preventive Medicine, Elsevier, Vol 24 No.3s, 2003.

Arifin, Muzayyin,Filsafat Pendidikan Islam, Jakarta: Bumi Aksara, 2003.

As'ad dan Budiyanto, Pedoman Pengelolaan, Pembinaan, dan Pengembangan TPA-TPA Nasional, Yogyakarta: LPTQ Nasional, 1995.

Bungin, Burhan,Penelitian Kualitatif,Jakarta: Kencana, 2007. 
46 | Jumiatmoko

Dahlan, MD, Pendidikan Anak Menurut Islam Kaidah-kaidah Dasar, Bandung: Remaja Rosdakarya, 1992.

Daradjat, Zakiyah, 1976. Ilmu Jiwa Agama, Jakarta: Bilan Bintang.

Direktorat Pembinaan Pendidikan Anak Usia Dini, 2015. Petunjuk Teknis Penyelenggaraan PAUD Berbasis Pendidikan Agama Islam, Jakarta: Dirjen PAUD dan Dikmas Kemdikbud.

Djalal, Fasli \& Supriadi, Dedi, 2001. Reformasi Pendidikan dalam Konteks Otonomi Daerah, Bandung: PT. Rafika Aditama.

Hariwijaya, 2009. PAUD Melejitkan Potensi Anak dengan Pendidikan Sejak Dini, Yogyakarta: Mahardika Publicity.

Idris, Chairani \& Karim, Tasyrifin, 1995. Pedoman Pembinaan dan Pengembangan TKA/TPA, Jakarta: LPP TKA BKPRMI.

Karim, Tasyrifn, 2004. Panduan Kurikulum dan Pengajaran TKA/TPA, Jakarta: LPPTKA BKPRMI Pusat.

Kementerian Agama Kanwil Jabar, 2010. Petunjuk Teknis Pendirian dan Perpanjangan Ijin Penyelenggaraan TKQ/TPQ/TQA di Lingkungan Kanwil Kemenag Provinsi Jawa Barat, Bandung: Kemenag Jabar.

Mikkelsen, Britha, 1999. Metode Penelitian Partisipatoris dan Upaya-upaya Pemberdayaan: Sebuah Buku Pegangan Bagi Para Peneliti Lapangan, Jakarta: Yayasan Obor.

Miles, Matthew B \& Huberman, Michael A. 1992. Analisis Data Kualitatif. Jakarta: Universitas Indonesia Press.

Moleong,Lexy J. 2007. Metodologi Penelitian Kualitatif. Bandung:PT.Remaja Rosdakarya.

Muhammad,Zuhaili. 2002. Pentingnya Pendidikan Islam Sejak Dini. Jakarta: AH Ba’adillah Press.

Mulyana,Deddy. 2004. Metodologi Penelitian Kualitatif. Bandung: PT. Remaja Rosdakarya.

Mulyati. 2005. Peranan Taman Pendidikan Al Qur'an TPA At Thohiriyah Klampok Kecamatan Purworejo Kabupaten Banjarnegara dalam Pembinaan Akblak.Skripsi. UNNES.

Purwanto, M Ngalim. 1993. Psikologi Pendidikan. Jakarta: Balai Pustaka.

Shihab, M.Quraishal. 1992. Membumikan Al Qur'an. Bandung: Mizan

Soekanto, Soerjono. 1990. Sosiologi Pendidikan, Bandung: Jenius

Sujiono, Yuliani Nurani. 2011. Konsep Dasar Pendidikan Anak Usia Dini.Jakarta: PT Indeks.

Sukmadinata, Nana Syaodihal. 2005. Metode Penelitian Pendidikan.Bandung: PT. Remaja Rosdakarya.

Syaodih, Ernawulan \& Agusin, Mubiar. 2008. Bimbingan Konseling untuk Anak Usia Dini. 
Jakarta: Universitas Terbuka.

Windi.2009.Kontribusi Taman Pendidikan Al Qur'an terhadap Pencapaian Kompetensi Pembelajaran Pendidikan Agama Islam di Sekolah dalam Baca Tulis Al Qur'an.Skripsi. UIN Syarif Hidayatullah

Wiyani, Novan Ardy \& Barnawi. 2012. Format PAUD. Yogyakarta: Ar-ruzz Media. 
